\title{
Diurnal patterning of eight activities in 14 species of muroid rodents
}

\author{
DENIS J. BAUMGARDNER, SUSAN E. WARD, and DONALD A. DEWSBURY \\ University of Florida, Gainesville, Florida 32611
}

\begin{abstract}
The diurnal patterning of locomotion, stereotypy, grooming, eating, drinking, sleeping, postural readjustment, and inactivity was studied in 14 species of muroid rodents in the laboratory using a visual observation technique. Microtus canicaudus, $M$. montanus, $M$. ochrogaster, and $M$. pennsylvanicus exhibited acyclic activity patterns, while Peromyscus eremicus, P. gossypinus, P. leucopus, P. maniculatus bairdi, P. polionotus, Calomys callosus, Mus musculus, and Onychomvs leucogaster displayed nocturnality in their behavioral patterning. Rhabdomys pumilio exhibited crepuscular activities and Neofiber alleni displayed a complex pattern of nocturnality. Species differed in total amount of time spent per day for all activities but eating. The acyclicity of Microtus species appears to be related to high metabolic rates and a semifossorial life-style.
\end{abstract}

The purpose of this study was to provide a comparative assessment of activity patterns exhibited in the laboratory by members of a number of species belonging to the superfamily Muroidea. In order to furnish an adequate account of rodent activity patterns, a broad foundation of descriptive data should be available for a substantial number of species that bear close phylogenetic relatedness but typically occur throughout a wide range of habitats.

Previous investigators have evaluated the activity patterns of a large number of muroid species, concentrating primarily on species from the genera Microtus and Peromyscus (e.g., Layne, 1971; O. P. Pearson, 1960). A variety of methods have been utilized in these studies. Field studies of rodent activity patterns have included the use of direct field observations (e.g., Thompson, 1977), photographic techniques (e.g., Carley, Fleharty, \& Mares, 1970), trapping records (e.g., Birkenholz, 1963; Daan \& Slopsema, 1978), radio-telemetry (e.g., Shields \& Sjoberg, Note 1), track counts in the substrate (cited in Falls, 1968), and the smoked card technique (e.g., Sheppe, 1965). Although data drawn from the field by the use of such techniques provide an accounting of animal behavior under naturally encountered conditions, the behavior under consideration is additionally influenced by such uncontrolled factors as climatic changes, food availability, and other ecological variables. In addition, each technique has drawbacks stemming from inherent biases in the estimation of the actual occurrence of activities. Laboratory measurements, while not providing a description in the natural environment, have an advantage in allowing the control and manipulation of particular variables believed

This research was supported by Grant BNS78-05173 from the National Science Foundation. to influence the behaviors in question. Procedures used in the laboratory by various investigators include the use of running wheels (e.g., Kavanau, 1967), various types of stabilimeter cages (e.g., Stinson, 1960), direct observational techniques (e.g., Choate, 1972), the monitoring of food and water delivery systems (e.g., Toates, 1978; Toates \& Ewart, 1977), gates, treadles, and photocell beams activated by movement from one area to another (e.g., Cheeseman, 1977), ultrasonic measurement devices (e.g., Peacock, Hodge, \& Thomas, 1966), and metabolic rate monitors (e.g., Hart, 1952). The purpose of this study was to provide quantitative information on various individual activity patterns for a number of rodent species in a laboratory setting and to endeavor to relate such data to the phylogeny and ecology of these species.

\section{EXPERIMENT 1}

\footnotetext{
Method

Subjects. A total of 165 animals from 14 species of muroid rodents served as subjects. The following species were included: Peromyscus eremicus (cactus mice), $P$. gossypinus (cotton mice), P. leucopus (white-footed mice), $P$. maniculatus bairdi (deer mice), $P$. polionotus (old field mice), Microtus canicaudus (gray-tailed voles), $M$. montanus (montane voles), $M$. ochrogaster (prairie voles), $M$. pennsylvanicus (meadow voles), Calomys callosus (laucha de campo), Mus musculus (house mice), Neofiber alleni (round-tailed muskrats), Onychomys leucogaster (northern grasshopper mice), and Rhabdomys pumilio (African striped mice). With the exception of $N$. alleni, 12 males of each species between 90 and 120 days of age were observed. Nine $N$. alleni were used, and they ranged in age from 5 to 44 months. All animals were laboratory bred. Females were excluded from the study to avoid the imposition of estrous cycle variation on the results.

Housing conditions and Apparatus. All animals were maintained on a reversed 16:8 h photoperiod. For Microtus species, the lights came on at $2000 \mathrm{~h}$ and went off at $1200 \mathrm{~h}$. For all other species, the lights came on at $1730 \mathrm{~h}$ and went off at $0930 \mathrm{~h}$. White light was provided via overhead room illumination with dim red
} 
light continuously present. All animals except $N$. alleni were individually housed in clear plastic cages, $29 \times 19 \times 13 \mathrm{~cm}$. $N$. alleni were housed in cages measuring $38 \times 20 \times 48.5 \mathrm{~cm}$. San-i-cel was used as a substrate for all animal cages. Food and water were continuously available. Microtus and Neofiber were provided with both Purina laboratory animal and rabbit chows, while all other species were fed only Purina laboratory animai chow.

Procedure. The animals were placed into clean cages with new substrate and immediately transferred to the testing room to adapt to room conditions for $60 \mathrm{~h}$ prior to the beginning of recording periods. One of two observers conducted all recordings. Interobserver reliability was calculated on the basis of 100 measurements each for three $P . m$. bairdi and three $M$. ochrogaster. Interobserver agreement for the two observers was obtained by dividing the number of agreements by agreements plus disagreements and multiplying by 100 . Interobserver reliability for individual activity patterns ranged from $97 \%$ to $100 \%$. An average of 12 animals (range 6-18) were observed across each 24-h recording period. Observations were conducted every other hour within a 24-h period. Although this method entailed periodic disturbance of the animals, a 10-20-min period of adaptation to the observer served to minimize such intrusion. Little, if any, change in an animal's behavior was noted in the period prior to observations. Within each observation hour, the behavior of each animal was recorded once every $60 \mathrm{sec}$, using an instantaneous sampling procedure (Altmann, 1974). Behaviors were recorded by the observer on a checklist. An attempt was made to maintain a consistent scan duration, that is, the amount of time per complete scan of animals under observation at a given time. Scan durations varied as a function of light-dark phase, the number and species of animals being observed, and the individual observer, ranging from approximately 10 to $40 \mathrm{sec}$ per minute interval. Each animal was observed for one complete $24-\mathrm{h}$ cycle. Animals from various species were tested during the same cycle. That is, for any one $24-\mathrm{h}$ period, any combination of species having similar light onsetoffset times was observed. Each animal was scored as emitting or engaging in one of the following, mutually exclusive behaviors: sleep-behavioral quiescence with the eyelids closed; inactivitybehavioral quiescence with the eyelids open; postural readjustment -whole-body readjustments which occurred during bouts of sleep or inactivity, for example, stretching, yawning, etc.; locomotionmoving about the cage, sniffing, exploring the substrate; stereotypy-repetitive, relatively invariable movements, for example, back flips, gnawing of the cage, continuous circling, etc.; grooming-preening, scratching, licking, and biting of the animal's own body; eating - manipulation or ingestion of food items and substrate; and drinking-contact with the tip of the water-bottle spout and ingestion.

\section{Results}

Hour-by-hour analysis. Individual behavioral patterns were grouped into two broad composite categories: composite activity-locomotion, stereotypy, grooming, eating, and drinking-and composite inactivity-sleep and postural readjustment. The individual category of inactivity was not included in this analysis because of its apparent lack of relationship to other measures. The measure of inactivity may have been too inclusive to accurately assess sleep-related behaviors. As defined, inactivity included events such as freezing, which often occurred during bouts of locomotion and stereotypy as well as other measures of composite activity.

Figures 1a, 1b, 1c, and 1d present the percentage of intervals within an hour in which the animals engaged in composite activity or inactivity over the course of $24 \mathrm{~h}$. Four different activity patterns are to be noted. First, nocturnality is the most prevalent daily pattern. All species of the genus Peromyscus exhibited composite activity cycles with a unimodal activity peak occurring at approximately the midpoint of the dark phase. Similar nocturnal activity patterns were also apparent for $C$. callosus, $M$. musculus, and O. leucogaster.

The second pattern is that demonstrated by the Microtus species, which shows the greatest departure from diurnal patterning of any sort. Activity patterns of Microtus appeared acyclic in that no rhythmicity of any sort is apparent on an hour-by-hour analysis.

A third pattern is exhibited by $R$. pumilio, which appeared unique in exhibiting a very marked crepuscular rhythm with activity peaks occurring immediately prior to light onset and of fset.

The fourth pattern, characteristic of $N$. alleni, was complex, with a general increase in activity in the dark phase but a sharp curtailment of activity in the middle of that phase.

Generally, the daily trends of composite activities and inactivities were paralleled by similar patterning for the individual behaviors included in each category. However, some behaviors, for example, eating and drinking, often occurred at such low rates as not to appear to exhibit any cycle for some species.

Although data collected by instantaneous sampling are not appropriate to assess the sequence of activity patterns, it was independently noticed by both observers that rather long bouts of grooming typically preceded sleep.

Phase-by-phase analysis. Nocturnal ratios, indexes derived by calculating the total time spent in a given activity in the dark phase divided by the total time spent in that activity in the light phase, were obtained for all species for each behavior pattern. These were corrected for differences in duration of the light and dark phases. Graphic representation of these ratios is depicted in Figure 2. Values greater than one represent a higher percentage of behavior occurring nocturnally, whereas values of less than one denote a greater proportion of behavior occurring during the light phase. The nocturnal ratios of each behavior category show close agreement with the patterning of the composite indexes. In general, locomotion, stereotypy, grooming, eating, and drinking show similar periodicity, while sleep and postural readjustment show an inversely related time course but a similar periodicity. Inactivity shows the largest departure from cyclicity, showing no clear pattern across species.

Activity levels. The percentage of time that members of a species engaged in a particular behavior during the light phase, dark phase, and the entire day is shown in Table 1. These data exhibit some similarity within genera and a larger disparity among 

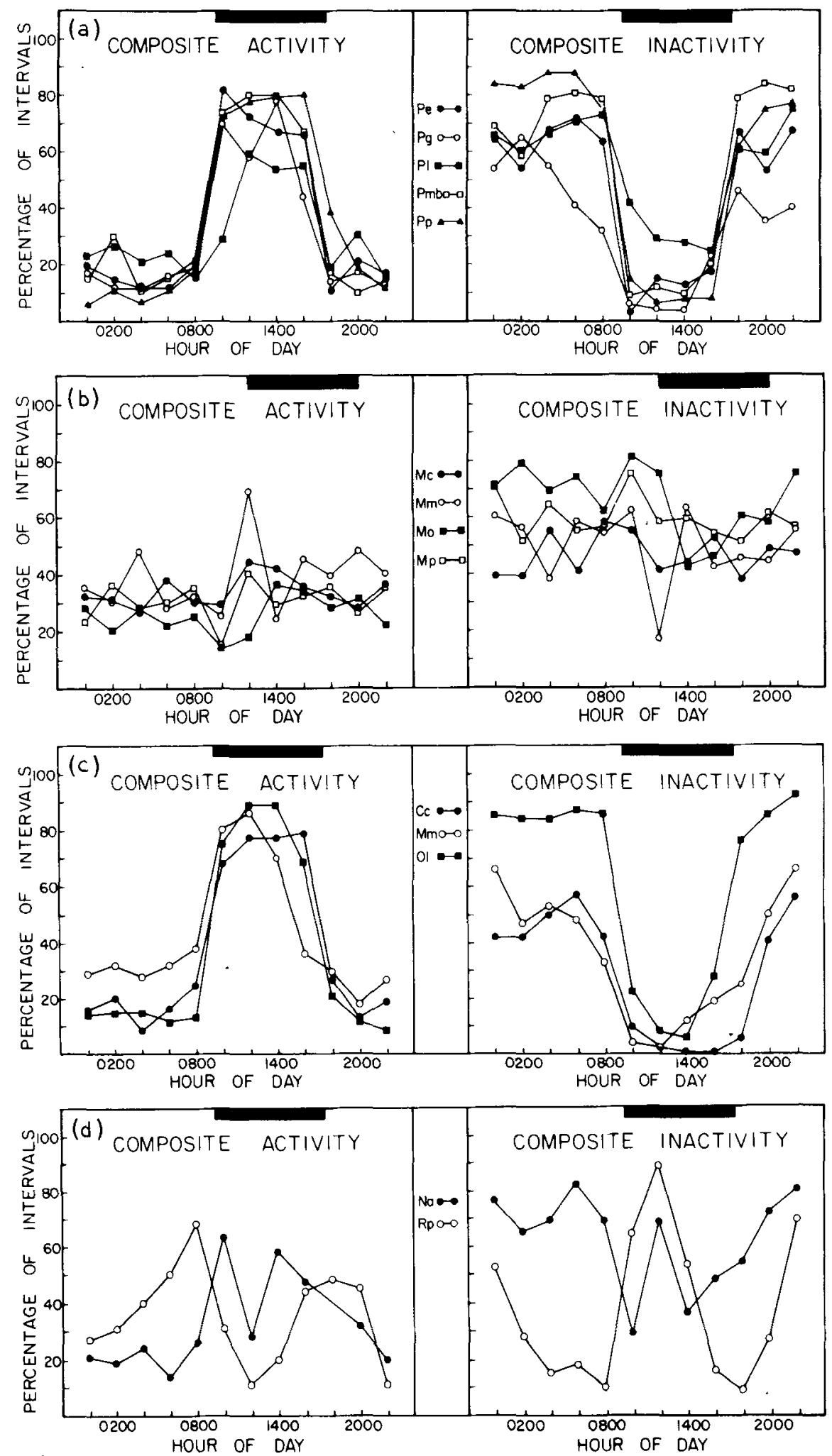

Figure 1. Percentage of intervals per hour spent in composite activity and inactivity for 14 species of muroid rodents in Experiment 1. Composite activity includes locomotion, stereotypy, grooming, eating, and drinking. Composite inactivity includes sleep and postural readjustment. The area underneath the dark bar represents the dark phase of the photoperiod. (a) $\mathrm{Pe}=$ $P$. eremicus; $\mathbf{P g}=P$. gossypinus; $\mathbf{P I}=P$. leucopus $; \mathbf{P m b}=P$. maniculatus bairdi $; \mathbf{P p}=$ P. polionotus; (b) $\mathbf{M c}=M$. canicaudus; $\mathbf{M m}=M$. montanus; $\mathbf{M o}=M$. ochrogaster; $\mathbf{M p}=$ $M$. pennsylvanicus; $(\mathrm{c}) \mathbf{C c}=C$. callosus; $\mathbf{M m}=M$. musculus; $\mathbf{O I}=O$. leucogaster; and (d) $\mathbf{N a}=N$. alleni; $\mathbf{R p}=R$. pumilio. 

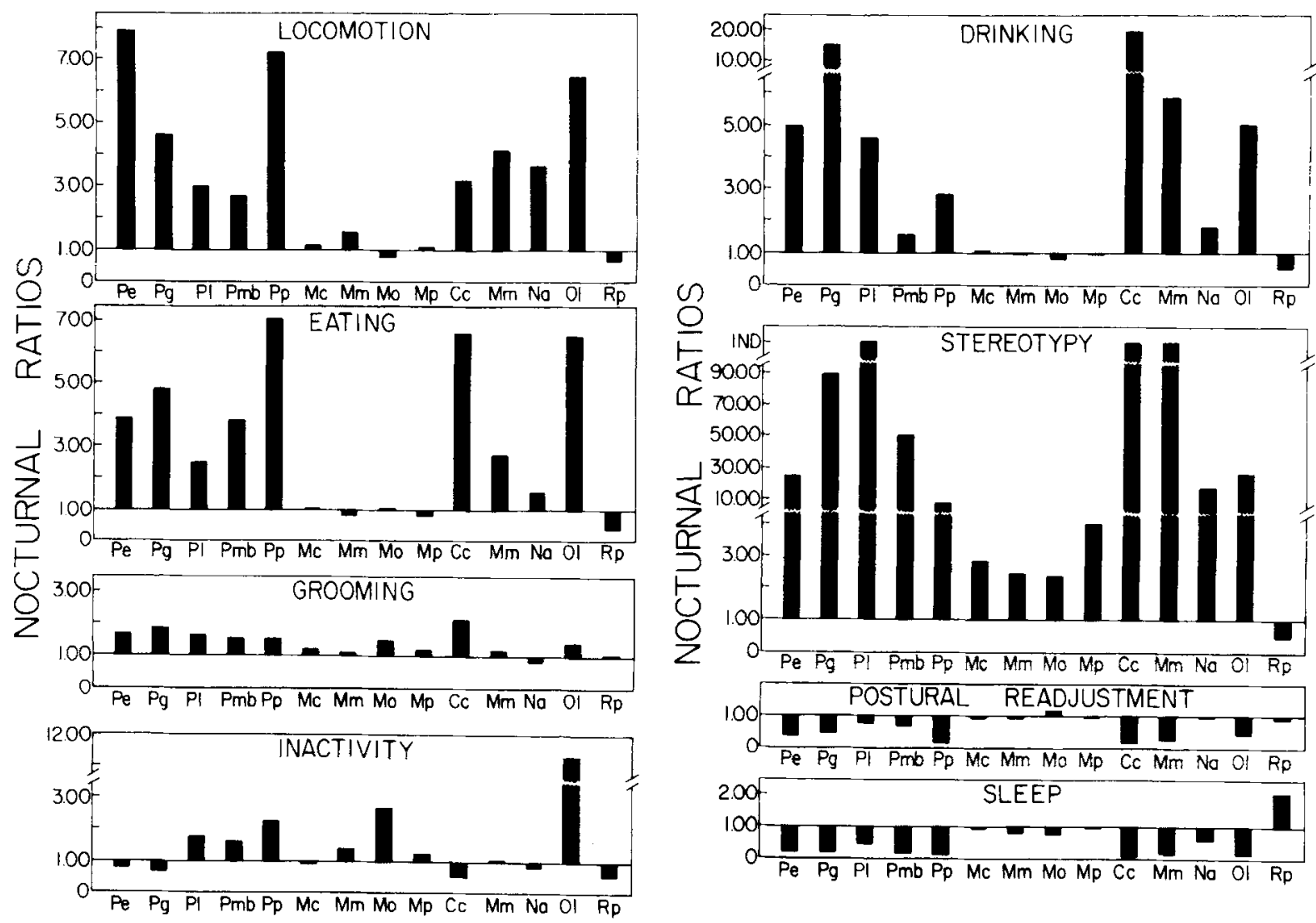

Figure 2. Nociurnal ratios of eight activities for 14 species of muroid rodents in Experiment 1. Nocturnal ratios are indexes derived by calculating the percentage of intervals spent in a given activity in the dark phase divided by the percentage of intervals spent in that activity in the light phase. Key: $\mathbf{P e}=P$. eremicus; $\mathbf{P g}=P$. gossypinus; $\mathbf{P I}=P$. leucopus; $\mathbf{P m b}=P$. maniculatus bairdi; $\mathbf{P p}=P$. polionotus; $\mathbf{M c}=M$. canicaudus; $\mathbf{M m}=M$. montanus; $\mathbf{M o}=M$. ochrogaster; $\mathbf{M p}=M$. pennsylvanicus; $\mathbf{C} \mathfrak{c}=C$. callosus; $\mathbf{M m}=M$. musculus; $\mathbf{N a}=N$, alleni $; \mathbf{O I}=0$. leucogaster $; \mathbf{R p}=R$. pumilio.

genera. One-way analyses of variance were conducted examining the percentage of intervals for the total day spent in each behavior for all 14 species. All tests showed highly significant differences between species, with $\mathrm{p}$ levels often substantially lower than $\mathrm{p}<.001$ [locomotion, $\mathrm{F}(13,154)=2.27$; stereotypy, $\mathrm{F}(13,154)$ $=2.58$; grooming, $\mathrm{F}(13,154)=8.54$; drinking, $F(13,154)=12.07$; sleep, $F(13,154=3.03$; postural readjustment, $F(13,154)=3.69$; and inactivity, $F(13,154)=20.09]$. Only eating failed to show any significant differences when analyzed across species $[\mathrm{F}(13,154)=1.14, \mathrm{p}<.33]$.

\section{EXPERIMENT 2}

Although data obtained in Experiment 1 strongly suggested significant differences in the cyclicity of Microtus and Peromyscus species, the possibility could not be excluded that the disparity between genera was due to the different diets and times of light onset/ offset to which the genera were exposed. Experiment 2 was conducted to assess the influence of these two variables on Microtus and Peromyscus activity patterns.

\section{Method}

Twelve male $M$. ochrogaster were maintained on Purina Lab Chow and exposed to a reversed $16: 8 \mathrm{~h}$ photoperiod, with light onset at $0930 \mathrm{~h}$. Twelve male $P . m$. bairdi were exposed to a similar photoperiod, except that light onset was at $1200 \mathrm{~h}$. The diet of these animals was Purina Rabbit Chow. All animals were under these conditions for 2 weeks prior to the beginning of behavioral observations. All other procedures were as stated in Experiment 1 .

\section{Results}

Figure 3 presents the percentage of intervals within an hour in which $M$. ochrogaster and $P . m$. bairdi engaged in composite activity and composite inactivity over a 24 -h period. It is apparent that $P$. $m$. bairdi exhibits a marked nocturnality while $M$. ochrogaster displays a relatively acyclic pattern of activity.

To compare the amount of time engaged in individual activities by $M$. ochrogaster and $P . m$. bairdi in Experiments 1 and 2, $t$ tests were performed. There were essentially no differences for $M$. ochrogaster, except that animals in the first experiment displayed more postural readjustment $[\mathrm{t}(11)=3.91, \mathrm{p}<.01]$.

$P$. m. bairdi in Experiment 1 exhibited less grooming $[\mathrm{t}=3.89, \mathrm{p}<.01]$ and more eating $[\mathrm{t}=2.65$, $\mathrm{p}<.05]$ than Peromyscus in Experiment 2. 
Table 1

Mean Percentages of Total Day, Light, and Dark Phases of Eight Behaviors for 14 Species of Muroid Rodents

\begin{tabular}{|c|c|c|c|c|c|c|c|c|c|}
\hline & $\begin{array}{l}\text { Percent- } \\
\text { age }\end{array}$ & $\begin{array}{l}\text { Loco- } \\
\text { motion }\end{array}$ & $\begin{array}{c}\text { Stereo- } \\
\text { typy }\end{array}$ & $\begin{array}{c}\text { Groom- } \\
\text { ing }\end{array}$ & $\begin{array}{c}\text { Eat- } \\
\text { ing }\end{array}$ & $\begin{array}{l}\text { Drink- } \\
\text { ing }\end{array}$ & ${ }_{\text {Sleep }}{ }^{P}$ & $\begin{array}{c}\text { Postural Read- } \\
\text { justment }\end{array}$ & $\begin{array}{l}\text { Inacti- } \\
\text { vity }\end{array}$ \\
\hline P. eremicus & $\begin{array}{l}\text { Dark } \\
\text { Light } \\
\text { Day }\end{array}$ & $\begin{array}{r}17.74 \\
2.22 \\
7.40\end{array}$ & $\begin{array}{r}22.15 \\
.85 \\
7.95\end{array}$ & $\begin{array}{r}13.89 \\
8.35 \\
10.20\end{array}$ & $\begin{array}{r}16.25 \\
4.22 \\
8.23\end{array}$ & $\begin{array}{r}1.70 \\
.35 \\
.80\end{array}$ & $\begin{array}{l}11.67 \\
62.60 \\
45.62\end{array}$ & $\begin{array}{r}56 \\
1.30 \\
1.05\end{array}$ & $\begin{array}{l}15.80 \\
19.98 \\
18.59\end{array}$ \\
\hline P. gossypinus & $\begin{array}{l}\text { Dark } \\
\text { Light } \\
\text { Day }\end{array}$ & $\begin{array}{r}21.91 \\
4.67 \\
10.42\end{array}$ & $\begin{array}{r}14.03 \\
.16 \\
4.78\end{array}$ & $\begin{array}{r}13.54 \\
7.41 \\
9.46\end{array}$ & $\begin{array}{r}11.53 \\
2.41 \\
5.45\end{array}$ & $\begin{array}{r}1.81 \\
.12 \\
.68\end{array}$ & $\begin{array}{r}8.44 \\
44.43 \\
32.43\end{array}$ & $\begin{array}{r}.80 \\
1.72 \\
1.41\end{array}$ & $\begin{array}{l}26.56 \\
38.49 \\
34.51\end{array}$ \\
\hline P. leucopus & $\begin{array}{l}\text { Dark } \\
\text { Light } \\
\text { Day }\end{array}$ & $\begin{array}{r}10.62 \\
3.49 \\
5.87\end{array}$ & $\begin{array}{r}2.05 \\
.00 \\
.68\end{array}$ & $\begin{array}{l}20.90 \\
12.41 \\
15.24\end{array}$ & $\begin{array}{r}14.72 \\
5.94 \\
8.87\end{array}$ & $\begin{array}{l}.80 \\
.17 \\
.38\end{array}$ & $\begin{array}{l}29.41 \\
65.10 \\
53.21\end{array}$ & $\begin{array}{l}1.32 \\
1.70 \\
1.57\end{array}$ & $\begin{array}{l}19.83 \\
11.34 \\
14.17\end{array}$ \\
\hline P. m. bairdi & $\begin{array}{l}\text { Dark } \\
\text { Light } \\
\text { Day }\end{array}$ & $\begin{array}{l}9.93 \\
3.65 \\
5.74\end{array}$ & $\begin{array}{r}36.84 \\
.71 \\
12.75\end{array}$ & $\begin{array}{r}11.35 \\
7.24 \\
8.38\end{array}$ & $\begin{array}{r}16.98 \\
4.41 \\
8.60\end{array}$ & $\begin{array}{l}.35 \\
.23 \\
.27\end{array}$ & $\begin{array}{l}11.81 \\
74.81 \\
53.81\end{array}$ & $\begin{array}{r}.90 \\
1.28 \\
1.16\end{array}$ & $\begin{array}{r}11.84 \\
7.52 \\
8.96\end{array}$ \\
\hline P. polionotus & $\begin{array}{l}\text { Dark } \\
\text { Light } \\
\text { Day }\end{array}$ & $\begin{array}{r}17.85 \\
2.47 \\
7.59\end{array}$ & $\begin{array}{r}32.15 \\
3.66 \\
13.16\end{array}$ & $\begin{array}{l}9.06 \\
6.06 \\
7.06\end{array}$ & $\begin{array}{r}18.09 \\
2.55 \\
7.72\end{array}$ & $\begin{array}{l}.49 \\
.17 \\
.59\end{array}$ & $\begin{array}{r}9.06 \\
77.62 \\
54.77\end{array}$ & $\begin{array}{r}.28 \\
1.53 \\
1.12\end{array}$ & $\begin{array}{r}13.06 \\
5.82 \\
8.23\end{array}$ \\
\hline M. canicaudus & $\begin{array}{l}\text { Dark } \\
\text { Light } \\
\text { Day }\end{array}$ & $\begin{array}{l}6.42 \\
5.78 \\
6.00\end{array}$ & $\begin{array}{l}4.13 \\
1.46 \\
2.35\end{array}$ & $\begin{array}{l}18.30 \\
15.24 \\
16.26\end{array}$ & $\begin{array}{l}6.94 \\
6.94 \\
6.94\end{array}$ & $\begin{array}{l}2.19 \\
2.12 \\
2.14\end{array}$ & $\begin{array}{l}42.64 \\
46.18 \\
45.00\end{array}$ & $\begin{array}{l}1.25 \\
1.39 \\
1.34\end{array}$ & $\begin{array}{l}17.78 \\
20.02 \\
19.27\end{array}$ \\
\hline M. montanus & $\begin{array}{l}\text { Dark } \\
\text { Light } \\
\text { Day }\end{array}$ & $\begin{array}{r}12.50 \\
8.09 \\
9.56\end{array}$ & $\begin{array}{l}7.22 \\
2.95 \\
4.38\end{array}$ & $\begin{array}{l}13.19 \\
11.79 \\
12.26\end{array}$ & $\begin{array}{r}8.78 \\
10.16 \\
9.70\end{array}$ & $\begin{array}{l}2.50 \\
2.76 \\
2.67\end{array}$ & $\begin{array}{l}39.72 \\
51.53 \\
47.59\end{array}$ & $\begin{array}{l}1.80 \\
2.00 \\
1.93\end{array}$ & $\begin{array}{l}14.27 \\
10.75 \\
11.92\end{array}$ \\
\hline M. ochrogaster & $\begin{array}{l}\text { Dark } \\
\text { Light } \\
\text { Day }\end{array}$ & $\begin{array}{l}4.13 \\
5.28 \\
5.02\end{array}$ & $\begin{array}{l}5.52 \\
2.40 \\
3.44\end{array}$ & $\begin{array}{r}11.84 \\
8.26 \\
9.46\end{array}$ & $\begin{array}{l}6.18 \\
5.87 \\
5.97\end{array}$ & $\begin{array}{l}1.18 \\
1.53 \\
1.41\end{array}$ & $\begin{array}{l}53.96 \\
69.08 \\
64.04\end{array}$ & $\begin{array}{l}2.26 \\
1.89 \\
2.01\end{array}$ & $\begin{array}{r}14.05 \\
5.42 \\
8.50\end{array}$ \\
\hline M. pennsylvanicus & $\begin{array}{l}\text { Dark } \\
\text { Light } \\
\text { Day }\end{array}$ & $\begin{array}{l}7.74 \\
7.31 \\
7.45\end{array}$ & $\begin{array}{l}5.31 \\
1.30 \\
2.64\end{array}$ & $\begin{array}{l}13.54 \\
11.30 \\
12.05\end{array}$ & $\begin{array}{l}4.27 \\
5.38 \\
5.01\end{array}$ & $\begin{array}{l}2.99 \\
3.26 \\
3.17\end{array}$ & $\begin{array}{l}53.54 \\
59.08 \\
57.23\end{array}$ & $\begin{array}{l}1.98 \\
2.14 \\
2.08\end{array}$ & $\begin{array}{l}12.74 \\
10.30 \\
11.11\end{array}$ \\
\hline C. callosus & $\begin{array}{l}\text { Dark } \\
\text { Light } \\
\text { Day }\end{array}$ & $\begin{array}{r}13.92 \\
4.41 \\
7.00\end{array}$ & $\begin{array}{r}10.76 \\
.00 \\
3.59\end{array}$ & $\begin{array}{r}19.90 \\
9.25 \\
12.80\end{array}$ & $\begin{array}{r}28.75 \\
4.34 \\
12.48\end{array}$ & $\begin{array}{r}1.91 \\
.10 \\
.71\end{array}$ & $\begin{array}{r}3.54 \\
41.96 \\
29.16\end{array}$ & $\begin{array}{r}.28 \\
1.42 \\
1.04\end{array}$ & $\begin{array}{l}22.08 \\
36.61 \\
33.10\end{array}$ \\
\hline M. musculus & $\begin{array}{l}\text { Dark } \\
\text { Light } \\
\text { Day }\end{array}$ & $\begin{array}{r}30.49 \\
7.36 \\
15.07\end{array}$ & $\begin{array}{r}3.78 \\
.00 \\
1.26\end{array}$ & $\begin{array}{l}19.20 \\
16.41 \\
17.34\end{array}$ & $\begin{array}{r}14.34 \\
5.28 \\
8.00\end{array}$ & $\begin{array}{l}.94 \\
.16 \\
.42\end{array}$ & $\begin{array}{r}8.68 \\
47.20 \\
34.36\end{array}$ & $\begin{array}{r}.35 \\
1.32 \\
1.00\end{array}$ & $\begin{array}{l}23.23 \\
22.24 \\
22.57\end{array}$ \\
\hline N. alleni & $\begin{array}{l}\text { Dark } \\
\text { Light } \\
\text { Day }\end{array}$ & $\begin{array}{r}21.71 \\
5.93 \\
11.19\end{array}$ & $\begin{array}{r}5.09 \\
.28 \\
1.88\end{array}$ & $\begin{array}{l}7.78 \\
9.19 \\
8.72\end{array}$ & $\begin{array}{l}9.21 \\
5.90 \\
7.01\end{array}$ & $\begin{array}{l}5.51 \\
3.12 \\
3.92\end{array}$ & $\begin{array}{l}44.03 \\
69.28 \\
60.86\end{array}$ & $\begin{array}{l}1.57 \\
1.67 \\
1.71\end{array}$ & $\begin{array}{l}5.09 \\
6.20 \\
5.83\end{array}$ \\
\hline O. leucogaster & $\begin{array}{l}\text { Dark } \\
\text { Light } \\
\text { Day }\end{array}$ & $\begin{array}{r}19.20 \\
3.00 \\
8.40\end{array}$ & $\begin{array}{r}32.15 \\
1.18 \\
11.50\end{array}$ & $\begin{array}{l}9.65 \\
6.82 \\
7.77\end{array}$ & $\begin{array}{r}16.98 \\
2.57 \\
7.37\end{array}$ & $\begin{array}{r}2.36 \\
.47 \\
1.10\end{array}$ & $\begin{array}{l}15.24 \\
83.16 \\
60.52\end{array}$ & $\begin{array}{r}.83 \\
1.86 \\
1.52\end{array}$ & $\begin{array}{r}12.27 \\
1.08 \\
1.97\end{array}$ \\
\hline R. pumilio & $\begin{array}{l}\text { Dark } \\
\text { Light } \\
\text { Day }\end{array}$ & $\begin{array}{r}9.41 \\
15.78 \\
13.66\end{array}$ & $\begin{array}{l}3.33 \\
6.96 \\
5.75\end{array}$ & $\begin{array}{l}8.40 \\
8.11 \\
8.21 \\
\end{array}$ & $\begin{array}{l}4.41 \\
9.79 \\
8.00 \\
\end{array}$ & $\begin{array}{r}.73 \\
1.27 \\
1.09 \\
\end{array}$ & $\begin{array}{l}54.44 \\
27.12 \\
36.23 \\
\end{array}$ & $\begin{array}{l}1.08 \\
1.34 \\
1.25 \\
\end{array}$ & $\begin{array}{l}18.19 \\
29.64 \\
25.82 \\
\end{array}$ \\
\hline
\end{tabular}

Thus, while there is a slight amount of variability in levels of individual activities, it should be emphasized that there were no differences in either composite activity, composite inactivity, or individual activity patterns (not shown) between $M$. ochrogaster and $P$. $m$. bairdi tested in Experiments 1 or 2 .

\section{GENERAL DISCUSSION}

The data reveal a marked difference between the activity rhythms of the two primary genera in this study. Those animals belonging to the genus Peromysus showed a nocturnal periodicity, while the Microtus exhibited an essentially acyclic pattern. All other species studied, with the exception of $R$. pumilio and $N$. alleni, exhibited nocturnally active behavior patterns, although the pattern of $N$. alleni is complex. $R$. pumilio was the sole species studied which displayed a crepuscular rhythm of activities.

Previous research on Peromyscus species indicates strong nocturnality within the genus. This is true for all of the species included in this study, including $P$. maniculatus (Carley et al., 1970), $P$. gossypinus (Layne, 1971), P. polionotus (Ehrhart, 1972), $P$. 


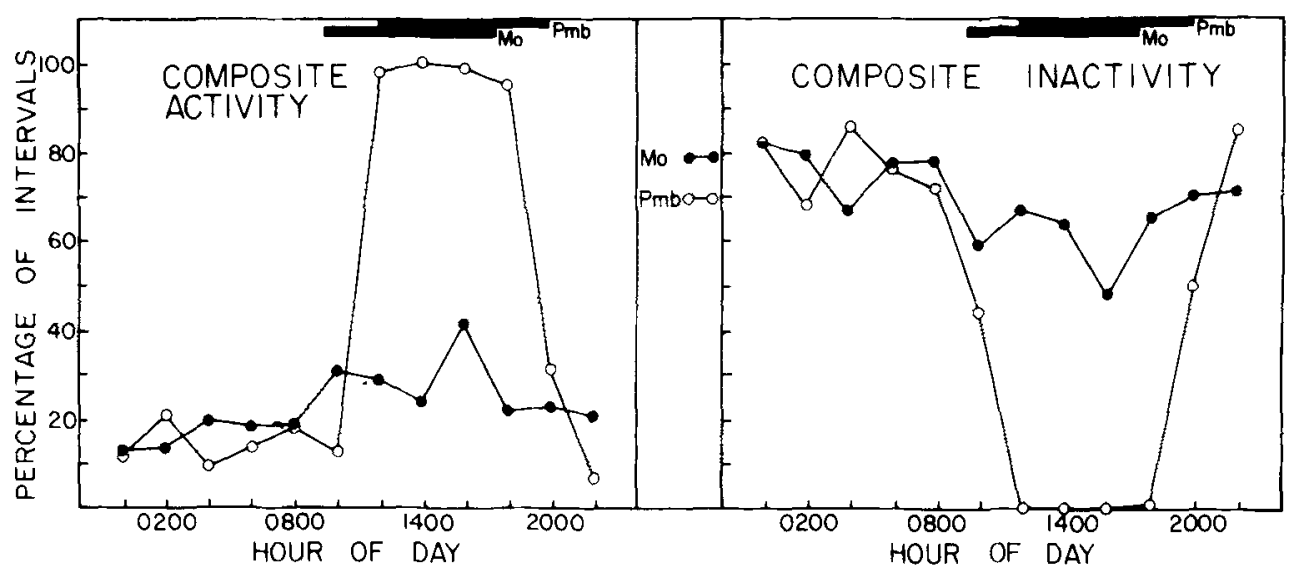

Figure 3. Percentage of intervals per hour spent in composite activity and composite inactivity for $M$. ochrogaster and $P$. $m$. bairdi in Experimeñt 2. Composite activity includes locomotion, stereotypy, grooming, eating, and drinking. Composite inactivity includes sleep and postural readjustment. The area under the upper dark bar represents the dark phase of the photoperiod of $P, m$. bairdi; the area under the lower dark bar represents the dark phase of the photoperiod of $M$. ochrogaster.

leucopus (Behney, 1936; Hill, 1972; Johnson, 1926; Orr, 1959; O. P. Pearson, 1947), and P. eremicus (Kavanau, 1978). One exception to such findings is for $P$. eremicus, which $\mathrm{McNab}$ and Morrison (1963) have studied in its desert habitat. They found that cactus mice were essentially crepuscular and believed this to be partially a function of high ambient temperature $\left(35^{\circ} \mathrm{C}\right)$. Stinson (cited in Falls, 1968) has provided sufficient evidence concerning the regulatory effect of temperature on activity. Given the moderate temperatures maintained in this study, the present finding that $P$. eremicus is nocturnal is probably congruent with previous data.

Activity patterns of Microtus have not been as thoroughly studied as those of Peromyscus, nor are the data so consistent within the genus. $M$. pennsylvanicus has been reported as being diurnal (Emlen, Hine, Fuller, \& Alfonso, 1957) and acyclic (Hamilton, $1937 \mathrm{a}, 1937 \mathrm{~b}$ ). The activity patterns of $M$. montanus have likewise been reported to be diurnal (Petterborg \& Negus, Note 2), nocturnal (Petterborg \& Negus, Note 2), and acyclic (Maser \& Storm, 1970). $M$. ochrogaster periodicity has been reported as being both diurnal (Carley et al., 1970; Martin, 1956) and nocturnal (Calhoun, 1945). We have been unable to locate any reports of activity patterns for $M$. canicaudus. All Microtus in this study uniformly displayed acyclic activity patterns.

Mus musculus is a nocturnal species (e.g., Aschoff, 1960), although some crepuscularity has been reported when activities are assessed via a stabilimeter cage (Aschoff \& Honma, 1959). Our findings indicate that this species is strongly nocturnal.

The activity patterns of $N$. alleni have not been intensively studied, but what information does exist suggests that this species is primarily nocturnal (Birkenholz, 1963, 1972). The nocturnal periodicity reported by Birkenholz is in general agreement with the data reported here, although he does note the finding of diurnal activity by one investigator.

$R$. pumilio has been reported to be chiefly diurnal (Choate, 1972; Delany \& Neal, 1966; Roberts, 1951; Shortridge, 1934). These reports are not consistent with the results of this study or those of Dewsbury and Dawson (1979), in which $R$. pumilio displayed a marked crepuscular rhythmicity for wheel running. Choate (1972), however, has conducted a combined laboratory and field investigation of Rhabdomys behavior. He, too, has found Rhabdomys to be largely diurnal, as assessed by visual observations recorded on an event recorder. The partial discrepancy between the results reported here and those of Choate may be attributable to his use of a smaller number of animals (two) and a different photoperiod (12:12) than used in this study. Furthermore, it should be noted that if one were to consider the nocturnal ratios derived from our data (see Figure 2), in fact, $R$. pumilio may best be described as being diurnal/ crepuscular in its patterning of activities.

As has been previously reported (Bailey, 1971), we have found $O$. leucogaster to be primarily nocturnal. We have been unable to locate any data pertaining to activity patterns of $C$. callosus. Our findings of strong nocturnality for this species appear typical for most rodents.

Table 2 presents information on species included in this study, including their periodicity, mode of living, and basal metabolic rates (BMR).

Metabolic rates obtained for other species of the genera Microtus and Peromyscus not included in this study appear quite similar to those included in this study. Basal metabolic rates $\left(\mathrm{cc} \mathrm{O}_{2} / \mathrm{g} / \mathrm{h}\right.$ ) for 15 taxa of Peromyscus species range from 1.03 to 1.79 (Glenn, 1970; MacMillen, 1965; McNab \& Morrison, 1963; 
Table 2

Periodicity of Rodents Included in This Study Together With Information on Mode of Living and Basal Metabolic Rates

\begin{tabular}{|c|c|c|c|c|}
\hline Species & NR & Mode of Living & $\begin{array}{l}\text { Basal Metabolic Rate* } \\
\left(\text { cc } \mathrm{O}_{2} / \mathrm{g} / \mathrm{h}\right)\end{array}$ & Source (BMR) \\
\hline P. eremicus & 4.49 & terrestrial & $1.48-1.60(1.56)$ & McNab \& Morrison, 1963; Macmillen, 1965 \\
\hline P. gossypinus & 4.25 & semiarboreal & 1.72 & Glenn, 1970 \\
\hline P. leucopus & 2.23 & semiarboreal & $1.46-1.63(1.55)$ & Morrison, 1948 \\
\hline P. m. bairdi & 4.65 & terrestrial & $1.55-1.65(1.60)$ & Morrison, 1948 \\
\hline P. polionotus & 5.21 & terrestrial/semifossorial & 1.79 & Glenn, 1970 \\
\hline M. canicaudus & 1.20 & semifossorial & 2.50 & McNab, Note 3 \\
\hline M. montanus & 1.24 & semifossorial & 2.65 & Packard, 1968 \\
\hline M. ochrogaster & 1.23 & semifossorial & 2.20 & McNab, Note 3 \\
\hline$M$. pennsylvanicus & 1.19 & semifossorial & 2.77 & Wiegert, 1961 \\
\hline C. callosus & 4.16 & terrestrial & N/A & \\
\hline M. musculus & 2.35 & variable & $1.53-1.79(1.66)$ & Morrison, 1948 \\
\hline N. alleni & 2.02 & semiaquatic & .84 & McNab, Note 3 \\
\hline O. leucogaster & 5.72 & terrestrial/semifossorial & 1.30 & Altman \& Dittmer, 1971 \\
\hline R. pumilio & .63 & terrestrial & N/A & \\
\hline
\end{tabular}

NOTE-NR = nocturnal ratios of composite activity.

*The BMR given in parentheses designates the figure used in computing the correlations described in the text.

Morrison, 1948; O. P. Pearson, 1947), while metabolic rates for 11 taxa of microtines (excluding $N$. alleni) range from 2.20 to 3.14 (Bienkowski \& Marszalek, 1974; Daan \& Slopsema, 1978; Gorecki, 1968; Hanson \& Grodzinski, 1970; Packard, 1968; A. M. Pearson, 1962; O. P. Pearson, 1947; Wiegert, 1961; McNab, Note 3). Such disparity between genera appears to be correlated with the periodicity of activity patterns for the genera. A Pearson productmoment correlation coefficient was calculated to assess any relationship existing between basal metabolic rate and the nocturnal ratio of composite activity for the 12 species in this study for which both types of information were available. Although possibly suggestive of the direction of relationship, the degree of relationship appears to be moderate $(r=$ -.56 ), perhaps attributable in part to the small number of species that could be examined here. When the relationship between BMR and composite inactivity is examined, however, a significant correlation was found to exist $(r=.64, p<.05)$. When only Microtus and Peromyscus species were included in the analysis, substantially higher correlations were found to exist for both composite activity and BMR $(r=.79$, $\mathrm{p}<.02)$ and composite inactivity and BMR $(r=.89$, $\mathrm{p}<.001$ ).

Mann-Whitney U tests were conducted comparing Microtus and Peromyscus species on the measures of composite activity, composite inactivity, and BMR. Although none of the Microtus data were overlapping with those of the Peromyscus species, only a comparison of composite activity between the two genera was found to be statistically significant $(p<.008)$.

Microtus species are believed to be one of the few forms of small mammals which exhibit substantial activity in the daytime, due in part to feeding within dense cover and having great food requirements (Cloudsley-Thompson, 1961). All Microtus species studied share what is an essentially semifossorial existence (e.g., Hooper \& Hart, 1962), live in moderately cold environments, and appear to require feeding at regular intervals throughout the day (Daan \& Slopsema, 1978; Hatfield, 1940; Kavanau \& Havenhill, 1976). Such ecological factors which relate directly to energetic requirements have determined, in part, the relatively high metabolic rates these animals exhibit as compared to those of other muroid rodents. Because of the high nutritional and energetic requirements imposed by such factors, it follows that these semifossorial rodents would by necessity evolve in such a way as to regulate their food intake so as to meet the demands of their high metabolism. One strategy for maintaining such high levels of energy intake might be to exhibit relatively acyclic patterns of locomotion and exploration along with concomitantly high levels of ingestive behavior at all times of the day.

One very interesting, and potentially conflicting, piece of information pertains to the finding that eating was the only behavior which, when analyzed in terms of percentage of $24 \mathrm{~h}$ spent in that activity, failed to show significant species differences. All other individual activities showed remarkably large species differences for such percentages. If, as has been hypothesized here, voles exhibit acyclic behavior patterns due to high energetic requirements, why then should all species show equivalent values for time during the day spent eating? One possibility is that our measure of eating was too unrefined to assess accurately the true percentage of time spent in eating behavior. Nibbling the substrate was included in this category due to the inability to distinguish food from all other foreign items under the current testing conditions. Furthermore, both duration of eating bouts and the type and amount of food consumed may differ substantially among the genera. Several qualifications must be made regarding the 
data obtained in this study. First, it should be noted that the photoperiods were step-changed. Kavanau (e.g., 1967) has demonstrated, for at least some of the species included in this study, that the presence of artificial twilights may influence the running speed of rodents in running wheels.

Second, Rusak and Zucker (1975) have reviewed evidence suggesting that the addition of a continuously darkened area to a laboratory environment, analogous to a nesting site in the natural habitat, may alter activity and feeding patterns exhibited by at least some species of rodents. The animals in this study had no such available area.

Finally, the animals in the two primary genera in this study were maintained on different diets and were subject to different times of light onset/offset. The particular settings of light onset/offset and the selection of the diets employed in this study were those which had proven optimal for the maintenance of laboratory breeding in these species. Data obtained in Experiment 2 strongly suggest that the influence of these variables is negligible, at least under the conditions employed in this study. When the diet and times of light onset/offset were reversed for $P$. $m$. bairdi and $M$. ochrogaster, both species continued to exhibit the patterns of cyclicity found for these animals in Experiment 1.

Of interest here is the recent work by Daan and Slopsema (1978) with Microtus arvalis, which is characterized by a high metabolic rate and acyclic activity rhythm. They assessed short-term activity patterns in the field via trapping records and then monitored running-wheel activity and ingestive behavior in the laboratory with the same animals. While runningwheel activity was exhibited virtually only during the dark phase, feeding occurred throughout both light and dark phases. When the photoperiod was altered, subjecting the animals to continuous darkness, both running-wheel activity and feeding activity remained the same as that shown on a LD 12:12 photoperiod. The only disparity was that the temporal patterning now approximated a cycle of slightly greater than $24 \mathrm{~h}$ in length. This finding, along with that of Lehmann (1976) with $M$. agrestis, which was exposed to continuous light, strongly suggests that this meal patterning is of endogenous origin and not dependent on light changes.

In summary, the acyclicity of Microtus species appears to be determined in part by their relatively cold habitat, which serves to promote high metabolic rates in these animals. So as to maintain these metabolic rates while ingesting low nutritional food, Microtus must apparently remain active throughout the day, unlike the nocturnal activity typical of most rodents.

\section{REFERENCE NOTES}

1. Shields, L. J., \& Sjoberg, S. The activity patterns of freeranging deer mice, Peromyscus californicus. Paper presented at the meeting of the American Society of Mammalogists, Athens, Georgia, June 1978.

2. Petterborg, L., \& Negus, N. C. Activity patterns in Microtus montanus. Paper presented at the meeting of the American Society of Mammalogists, Athens, Georgia, June 1978.

3. McNab, B. Personal communication, March 1979.

\section{REFERENCES}

Altman, P. L., \& Dittmer, D. S. Respiration and circulation. Bethesda, Md: Federation of American Societies for Experimental Biology, 1971.

AltmanN, J. Observational study of behavior: Sampling methods. Behaviour, 1974, 49, 227-267.

Aschoff, J. Exogenous and endogenous components in circadian rhythms. Cold Spring Harbor Symposium on Quantitative Biology, 1960, 25, 11-28.

Aschoff, J., \& Honma, K. Art- und Individualmuster der Tagesperiodik. Zeitschrift für Vergleichende Physiologie, 1959, 42, 383-392.

BAILEy, V. Mammals of the Southwestern United States. New York: Dover, 1971.

BEHNEY, W. H. Nocturnal explorations of the forest deer mouse. Journal of Mammalogy, 1936, 17, 225-230.

Bienkowski, P., \& Marszalek, V. Metabolism and energy budget in the snow vole. Acta Theriologica, 1974, 19, 55-67.

Birkenholz, D. E. A study of the life history and ecology of the round-tailed muskrat (Neofiber alleni true) in North-Central Florida. Ecological Monographs, 1963, 33, 255-280.

Birkenholz, D. E. Neofiber alleni. Mammalian Species, 1972, $15,1-4$.

Calmoun, J. B. Diel activity rhythms of the rodents Microtus ochrogaster and Sigmodon hispidus. Ecology, 1945, 26, 251-273.

Carley, C. V., Fleharty, E. D., \& Mares, M. A. Occurrence and activity of Reithrodontomys megalotis, Microtusochrogaster, and Peromyscus maniculatus as recorded by a photographic device. Southwestern Naturalist, 1970, 15, 209-216.

Cheeseman, C. L. Activity patterns of rodents in Rwenzori National Park, Uganda. East African Wildlife Journal, 1977, 15, 281-287.

Choate, T. S. Behavioral studies on some Rhodesian rodents. Zoologica Africana, 1972, 7, 103-118.

Cloudsle Y-Thompson, J. L. Rhythmic activity in animal physiology and behaviour. New York: Academic Press, 1961.

DAAN, S., \& Slopsema, S. Short term rhythms in foraging behaviour of the common vole, Microtus arvalis. Journal of Comparative Physiology- $A, 1978,127,215-227$.

Delany, M. J., \& Neal, B. R. A review of the Muridae (order Rodentia) of Uganda. Bulletin of the British Museum (Natural History) Zoology, 1966, 13, 297-353.

Dewsbury, D. A., \& Dawson, W. W. African four-striped grass mice (Rhabdomys pumilio), a diurnal-crepuscular muroid rodent in the behavioral laboratory. Behavior Research Methods \& Instrumentation, 1979, 11, 329-333.

Ehrhart, L. M. Behavioral studies of three species of the oldfield mouse. Peromyscus polionotus (Doctoral dissertation, Cornell University). Dissertation Abstracts International, 1972, 328, 6735B-6736. (University Microfilms, No. 72-13, 154)

Emlen, J. T., Hine, R. L., Fuller, W. A., \& Alfonso, P. Dropping boards for population studies of small mammals. Journal of Wildlife Management, 1957, 21, 300-314.

F Alls, J. B. Activity. In J. A. King (Ed.), Biology of Peromyscus (Rodentia). Lawrence, Kans: American Society of Mammalogists, 1968.

Glenn, M. E. Water relations in three species of deer mice (Peromyscus). Comparative Biochemistry and Physiology, 1970, $33,231-248$

Goreck I, A. Metabolic rate and energy budget in the bank vole. Acta Theriologica, 1968, 13, 341-365.

Hamiliton, W. J., JR. Growth and life span of the field mouse. American Naturalist, 1937, 71, 500-507. (a) 
Hamilton, W. J., JR. Activity and home range of the field mouse, Microtus pennsylvanicus (Ord). Ecology, 1937, 18, 255-263. (b)

Hanson, L., \& Grodzinski, W. Bioenergetic parameters of the field vole Microtus agrestis L. Oikos, 1970, 21, 76-82.

HART, J. S. Effects of temperature and work on metabolism, body temperature, and insulation: Results with mice. Canadian Journal of Zoology, 1952, 31, 99-105.

Hatfield, D. M. Activity and food consumption in Microtus and Peromyscus. Journal of Mammalogy, 1940, 21, 29-36.

HiLL, R. W. The amount of maternal care in Peromyscus leucopus and its thermal significance for the young. Journal of Mammalogy, 1972, 53, 774-790.

Hooper, E. T., \& Hart, B. S. A synopsis of recent North American microtine rodents. Miscellaneous Publications of the Museum of Zoology, University of Michigan, 1962, 120, 1-68.

JoHnson, M. S. Activity and distribution of certain wild mice in relation to biotic communities. Journal of Mammalogy, 1926, 7, 245-277.

Kavanau, J. L. Behavior of captive white-footed mice. Science, $1967,155,1623-1639$.

KavanaU, J. L. Compulsory regime and control of environment in animal behavior. IV. Light level preferences of cactus mice. Peromyscus eremicus. Behaviour, 1978, 65, 161-181.

Kavanau, J. L., \& Havenhill, R. M. Compulsory regime and control of environment in animal behaviour. III. Light level preferences of small nocturnal mammals. Behaviour, 1976, 59, 203-225.

LAYNE, J. N. Activity responses of two species of Peromyscus (Rodentia, Muridae) to varying light cycles. Oecologia, 1971, 7, 223-241.

LEHMANN, V. Short-term and circadian rhythms in the behaviour of the vole. Microtus agrestis (L). Oecologia, 1976, 23, 185-199.

MacMillen, R. E. Aestivation in the cactus mouse, Peromyscus eremicus. Comparative Biochemistry and Physiology, 1965, 16, 227-248.

Martin, E. P. A population study of the prairie vole (Microtus ochrogaster) in Northeastern Kansas. University of Kansas Publications of the Museum of Natural History, 1956, 8, 361-416.

Maser, C., \& Storm, R. M. A key of Microtinae of the Pacific Northwest. Corvallis, Oreg: O.S.U. Book Stores, 1970.

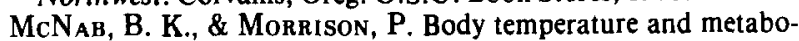
lism in subspecies of Peromyscus from arid and mesic environments. Ecological Monographs, 1963, 33, 63-82.
Morrison, P. R. Oxygen consumption in several mammals under basal conditions. Journal of Cellular and Comparative Physiology, 1948, 31, 281-291.

ORR, H. D. Activity of white-footed mice in relation to environment. Journal of Mammalogy, 1959, 40, 213-221.

PACKARD, G. C. Oxygen consumption of Microtus montanus in relation to ambient temperature. Journal of Mammalogy, 1968, 49, 215-270.

Peacock, C. V., Hodge, M. H., \& Thomas, R. K. Ultrasonic measurement and automatic analysis of general activity in the rat. Journal of Comparative and Physiological Psychology, 1966, 62, 284-288.

Pearson, A. M. Activity patterns, energy metabolism and growth rate of the voles Clethrionomys rufocanus and $C$. glareolus in Finland. Annales Zoologici Societatis "Vanamo," 1962, 24, 1-58.

Pearson, O. P. The rate of metabolism of some small mammals. Ecology, 1947, 28, 127-145.

Pearson, O. P. Habits of Microtus californicus revealed by automatic photographic recorders. Ecological Monographs, 1960, 30, 231-249.

RoBerts, A. The mammals of South Africa. New York: Hafner, 1951.

RuSAK, B., \& ZUCKER, I. Biological rhythms and animal behavior. Annual Review of Psychology, 1975, 26, 137-171.

Sheppe, W. Characteristics and uses of Peromyscus tracking data. Ecology, 1965, 46, 630-634.

Shortridge, G. C. The mammals of South West Africa (Vol. 1). London: William Heinemann, 1934.

Stinson, R. H. The timing of the activity pattern of Peromyscus in constant darkness. Canadian Journal of Zoology, 1960, 38, $51-55$.

Thompson, D. C. Diurnal and seasonal activity of the grey squirrel, Canadian Journal of Zoology, 1977, 55, 1185-1189.

Toates, F. M. A circadian rhythm of hoarding in the hamster. Animal Behaviour, 1978, 26, 637.

Toates, F. M., \& Ewart, B. Gerbil drinking patterns. Animal Behaviour, 1977, 25, 782-786.

WIEGÉRT, R. G. Respiratory energy loss and activity patterns in the meadow vole Microtus pennsylvanicus. Ecology, 1961, 42, 245-253.

(Received for publication July 3, 1979; revision accepted November $5,1979$. ) 